\title{
Trefoil Factor 2
}

National Cancer Institute

\section{Source}

National Cancer Institute. Trefoil Factor 2. NCI Thesaurus. Code C115190.

Trefoil factor 2 (129 aa, $\sim 14 \mathrm{kDa}$ ) is encoded by the human TFF2 gene. This protein is involved in the negative regulation of gastrointestinal motility and gastric acid secretion. 